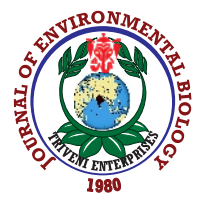

\title{
Soil application of boron impacts its solubility, yield and fibre quality of cotton in calcareous soils of North-western India
}

\author{
S. Kumar ${ }^{1 *}$, D. Kumar', K.S. Sekhon', P. Singh ${ }^{3}$, M. Phogat and O.P. Choudhary ${ }^{1}$ \\ 'Department of Soil Science, Punjab Agricultural University, Ludhiana-141 004, India \\ ${ }^{2}$ Soil Physicist, Regional Research Station, Punjab Agricultural University, Bathinda-151 001, India \\ ${ }^{3}$ District Extension Specialist (Soil Science), Farm Advisory Service Centre (FASC), Bathinda-151 001, India \\ ${ }^{4}$ Department of Soil Science, Chaudhary Charan Singh, HaryanaAgricultural University, Hisar-125 004, India \\ *Corresponding Author Email : sunilsngwn7@gmail.com
}

\section{Abstract}

Aim: To investigate that application of boron $\left(0-2.5 \mathrm{mg} \mathrm{kg}^{-1}\right.$ soil, as borax and granubor) to calcareous soil in North-western India affectes its solubility in soil, yield and fibre quality characters of cotton (Gossypium hirsutum L.).

Methodology: A field study was conducted to estimate and enumerate the influence of B application (as borax and granubor @ 0-2.5 mg B kg-1 soil; $\mathrm{B}_{0}$ $B_{2.5}$ ) on cotton yield and yield contributing attributes ascribed to change in different fractions of variable solubility in $B$ deficient (available $B=0.21 \mathrm{mg} \mathrm{kg}^{-1}$ ) calcareous sandy loam soil. This field experiment was set up in a plot size of $2.7 \mathrm{~m}$ X $3.75 \mathrm{~m}$ with three replications arranged in RBD in factorial combinations.

Results: Mean lint and cotton seed yield increased significantly under $B_{1.0}$, compared with control $\left(B_{0}\right)$. Boron concentration in roots, leaves, petioles, bolls, sympodial and monopodial branches, seeds and lint increased significantly $(p<0.05)$ with $1.0 \mathrm{mg} \mathrm{B} \mathrm{kg}^{-1}$ application $\left(\mathrm{B}_{1.0}\right)$. Boron application $\left(\mathrm{B}_{2.0}\right)$ significantly augmented the mean uniformity ratio by $\sim 4.8 \%$, compared with $\mathrm{B}_{0}$, while the fibre strength and staple length increased significantly in $\mathrm{B}_{1.5}$ treatment. The micronaire value of lint decreased significantly from 4.84 (in $\mathrm{B}_{0}$ ) to $4.25 \mu \mathrm{g} \mathrm{inch}{ }^{-1}$ in $\mathrm{B}_{2.5}$ treated plots. Boron application caused notable augmentation in $\mathrm{B}$ concentration in its reservoirs/pools of variable solubility; oxide bound fraction being smallest $(\sim 0.34 \%$ of total $B)$, while residual $B$ the largest fraction ( $95 \%$ of total $B$ ). Boron sources had meagre affect and did not vary remarkably for $B$ concentration in different vegetative plant parts, cotton yield and contributing attributes and $B$ fractions of variable solubility in calcareous soil.

Interpretation: The findings of study divulged that soil applied B significantly

Soil boron application $\left(0,0.5,1.0,1.5,2.0\right.$, and $2.5 \mathrm{mg} \mathrm{B} \mathrm{kg}^{-1}$ soil, as borax and granubor) to boron deficient calcareous soil

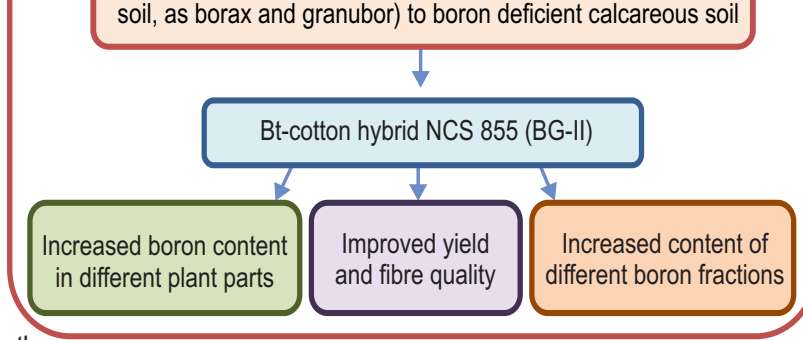

$$
\text { y }
$$
augmented cotton yield and its yield contributing attributes owing to augmented solubility of $B$ in a calcareous soil. Different $B$ fractions evinced a significant $(p<0.05)$ relationship with yield attributes, indicating their significance for increased B uptake which impacts the seed cotton yield in a calcareous soil. These experimental outcomes highlight the overwhelming significance of soil application of B for increased cotton productivity with improved fibre quality.

Key words: Boron, Chemical fractionation, Cotton, Fibre quality, Granubor

How to cite : Kumar, S., D. Kumar, K.S. Sekhon, P. Singh, M. Phogat and O.P. Choudhary: Soil application of boron impacts its solubility, yield and fibre quality of cotton in calcareous soils of North-western India. J. Environ. Biol., 42, 1534-1543 (2021). 


\section{Introduction}

Amidst identified micro-nutrients deficiencies, the pervasiveness of boron paucity is second only to zinc stifling crop growth/development, and hence, production in different agroecosystems across the globe. Boron shortfall has been detected in calcite containing soils of arid and semi-arid regions in over 100 crops across 80 countries (including India). Boron deficiency has been reported in 5 to $10 \%$ soils of north-western India encompassing $\sim 43 \%$ soil series, i.e. out of seven soil series, three are boron deficit (Arora and Chahal 2005). Soils with substantial amount of calcite content, leads to boron adsorption and acts as its sink by virtue of firm boron fixation on $\mathrm{CaCO}_{3}$ particle surface. In soil environment, boron occurs in distinct forms having variable solubility phases (Hou et al., 1996).

For decades, the boiling water extractable fraction is regarded as a key indicator of boron availability to plant roots, yet there are contradictory evidences divulging that this fraction has no any noteworthy relationship with plant uptake/growth (Sims and Johnson 1991). Boron application affects its pool size as each fraction equilibrate with each other to influences boron availability to plant (Xu et al., 2001). Plant useable boron form, on the other hand, varies greatly relying on plant species (Tsalidas et al., 1994). Soil boron content manifest positive relationship not only with equilibrium boron concentration, but also to specific-and non-specific adsorbed and Mn oxy-hydroxides occluded boron pool (Jin et al., 1987). Its concentration in leaves of Olea europaea L. exhibit linear relationship with oxy-hydroxide (Fe and $\mathrm{Al}$ ) occluded, adsorbed and Mn oxy-hydroxide occluded B fractions (Tsalidas et al., 1994). Sidhu and Kumar (2018) reported that above-and below-ground biomass yield of Trifolium alexandrinum $\mathrm{L}$. is linearly related to soluble besides organic matter bound boron pool. Padbhushan et al. (2019) assessed and manifested positive rapport amidst curd yield of Brassica oleracea with soluble and adsorbed boron fractions in soil. Therefore, for improved insight on boron dynamics, scrutinizing studies pertaining to its fractionation exploration are important to establish relationship with boron concentration in above-ground crop biomass (Sarkar et al., 2018). Boron availability significantly decreases in the presence high $\mathrm{CaCO}_{3}$ leading to yield loss (Padbhushan et al., 2019).

Boron application has notable imprints on distinct phases of plant growth and development viz., fruit abscission, seed development and pollen formation and fertilization etc. Boron is globally recognised as a critical/essential nutrient for cotton production, and cotton, owing to higher boron requirements, is especially vulnerable to boron paucity (Shorrocks 1992). Boron availability, particularly during pollen germination/formation, blooming and boll formation stages, has been documented amongst most crucial factor in augmenting crop productivity (Rashidi et al., 2011; Sharma et al., 2019). The genetic makeup of cotton plants regulates fiber traits (Hearn 1981), but growing conditions determine whether the quality of fiber reaches the genetic potential (Yeates et al., 2010). Boron's optimum availability is imperative for optimization of quality characters of cotton's fibre (Tewolde and Fernandez, 2003). Cotton ovules grown in-vitro culture have shown abnormal fiber growth under boron stress environment (Birnbaum et al., 1974). Till date, there exists disparity on boron application consequence on lint and seed cotton production, yield contributing characters and cotton's fibre quality traits. The recent revelation revealed that $B$ application manifested an optimising and notable impact on the fibre quality characteristics of cotton (Rahman et al., 2018). Soils having calcareous environment, boron adsorption occurs ascribed to its large scale transformations among diverse chemical fractions of variable solubility, which controls boron availability in soil solution.

A comprehension of boron distribution amid different solubility pools and their rapport with crop response provides necessary insight to quantify boron availability to plants. Amidst commercial crops grown on wider scale, cotton has been historically considered amidst the most valuable natural fibre crops cultivated in arid and semi-arid circumstances in rotation with wheat/barley/mustard, where boron paucity exerts significant set-back on crop growth/productivity and quality characteristics because of high $\mathrm{CaCO}_{3}$ content in soil. Reports on the consequence of boron application on cotton's fibre quality characteristics is scarce and conflicting. We speculated that boron added to the soil would have a noteworthy knock on cotton productivity, lint and seed yield pertaining attributes and cotton's fibre quality characteristics because of alteration in boron fractions of variable solubility. Therefore, main objective of present investigation was to appraise the consequences of boron application through different sources on its re-allotment amid fractions of variable solubility in calcareous soil and to establish relationship with cotton lint traits, concentration of boron in different cotton's plant parts and fibre excellence of cotton.

\section{Materials and Methods}

Soil site and its soil properties: The field experimental investigation was conducted at the experimental farm of Punjab Agricultural University, Regional Research Station, Bathinda, India. The investigation area was categoried under semi-arid and sub-tropical climate, having maximum and minimum temperatures on annual basis 30.4 and $17.3^{\circ} \mathrm{C}$, respectively, total annual rainfall and evapo-transpiration of 543 and $2258 \mathrm{~mm}$, respectively. About $80 \%$ of total annual rainfall is received in monsoon season extending between July-September, while 20\% rain falls in winter season. The surface $(0-15 \mathrm{~cm})$ soil was sandy loam in texture (sand $=66 \%$, silt=20\%, and clay $=14 \%$ ), slightly alkaline ( $\mathrm{pH}=8.42)$, non-saline (E.C. $\left.=0.174 \mathrm{dS} \mathrm{m}^{-1}\right)$, calcareous $(\mathrm{CaCO}=1.10 \%)$ with low oxidizable soil organic carbon (SOC=3.6 $\left.\mathrm{g} \mathrm{kg}^{-1}\right)$ and available- $\mathrm{N}\left(240.0 \mathrm{~kg} \mathrm{ha}^{-1}\right)$, high in available-P $(37.5 \mathrm{~kg}$ $\left.\mathrm{ha}^{-1}\right)$ and available-K(204.4 $\left.\mathrm{kg} \mathrm{ha}^{-1}\right)$.

Description of field treatments: Field treatments included two boron sources viz., borax $\left[\mathrm{Na}_{2}\left(\mathrm{~B}_{4} \mathrm{O}_{5}(\mathrm{OH})\right) .8 \mathrm{H}_{2} \mathrm{O}\right]$ and granubor $\left(\mathrm{Na}_{2} \mathrm{~B}_{4} \mathrm{O}_{7} .5 \mathrm{H}_{2} \mathrm{O}\right)$ applied at $0-2.5 \mathrm{mg} \mathrm{B} \mathrm{kg}{ }^{-1}$ soil $\left(\mathrm{B}_{0}-\mathrm{B}_{2.5}\right)$ with three replications (in $2.70 \times 3.75 \mathrm{~m}$ sized plots) arranged in completely randomized block design (RBD) in factorial combinations. American cotton hybrid NCS 855 BG-II (Raghav) was selected as test plant and sown in May month. The recommended dose of fertilizer- $\mathrm{N}\left(150 \mathrm{~kg} \mathrm{~N} \mathrm{ha}^{-1}\right)$ using urea 
$(46 \% \mathrm{~N})$ was incorporated in all treatments in two equal splits; first split dose ( $1 / 2$ of total dose) at first irrigation and second split dose ( $1 / 2$ of total dose) at flower initiation. Fertilizer-P application was skipped, as $\mathrm{P}$ at recommended rate was applied to wheat sown in proceeding winter season. Boron was applied at sowing. Cotton crop was sown at optimum soil moisture (field capacity moisture) content following heavy pre-sowing irrigation. Cotton was sown with maintaining row-to-row spacing of $67.5 \mathrm{~cm}$ i.e in rows $67.5 \mathrm{~cm}$ apart, while maintaining plant-to-plant spacing of $75 \mathrm{~cm}$. Cotton crop was flood irrigated with good quality canal irrigation water ( $\mathrm{pH}=7.4$ and E.C. 0.29 $\left.\mathrm{dS} \mathrm{m}^{-1}\right)$. The other packages of practices were as per recommendations of P.A.U., Ludhiana, Punjab, India.

Soil sample collection and sequential extraction technique: After harvesting the crop in $1^{\text {st }}$ week of November, a tube auger (inner diameter $7.2 \mathrm{~cm}$ ) was used to extract composite samples $(0-15 \mathrm{~cm})$ from each plot. The procured samples were naturally dried in shadow (air-dried), grinded (using ceramic pestle mortar), sieved ( $2.0 \mathrm{~mm}$ sieve) and thereafter stored in polythene bags for analysis. The plant available boron was extracted by using $10 \mathrm{mM}$ calcium chloride as extractant solvent (1:2; Soil: solution), succeeded by boron determination calorimetrically at $420 \mathrm{~nm}$ by using azomethine-H method (Gupta 1979). A sequential chemical extraction technique (Hou et al., 1996) was implemented for the partitioning of total content among fractions of different solubility viz. readily soluble- $B$, specifically adsorbed- $B$, oxide bound- $B$, organically bound- $B$ and residual or occluded-B. Readily soluble-boron was extracted after shaking $5 \mathrm{~g}$ soil+10 $\mathrm{ml} 0.01 \mathrm{M}$ calcium chloride for $16 \mathrm{~h}$ in $50 \mathrm{ml}$ centrifuge tubes subsequently centrifugation at $10000 \mathrm{rpm}$ for 30 min and boron was determined using azomethine- $\mathrm{H}$.

The leftover soil was kept as a whole in centrifuge and agitated after adding $10 \mathrm{ml}$ of $0.05 \mathrm{M}$ potassium dihydrogen phosphate for $1 \mathrm{hr}$, subsequently centrifugation and $B$ determination as adsorbed $B$. Oxide bound-B fraction was ascertained from the leftover soil shaken with $20 \mathrm{ml}$ of $0.2 \mathrm{M}$ $\mathrm{NH}_{4}$-oxalate adjusted to $\mathrm{pH}=3.25$ for $4 \mathrm{~h}$, followed by boron determination in yellowish to slightly reddish coloured extract. Organic matter bound boron pool was extracted from the leftover soil by adding $3 \mathrm{ml}$ of $0.02 \mathrm{M} \mathrm{HNO}_{3}+5 \mathrm{ml}$ of $30 \% \mathrm{H}_{2} \mathrm{O}_{2}$ (adjusted at $\mathrm{pH}=2$ ), followed by heating the mixture at $85^{\circ} \mathrm{C}$ in a water bath for $2 \mathrm{hr}$ with occasional agitation following standard procedure. Total boron in soil was determined with $\mathrm{Na}_{2} \mathrm{CO}_{3}$ fusion method (Berger and Truog 1944).

Plant analyses: Plant samples of various plant parts were drawn keenly from all plots during crop harvesting. The acquired samples were washed, dried (at $65 \pm 2^{\circ} \mathrm{C}$ ), and ground. Boron content was determined by ashing $0.5 \mathrm{~g}$ sample at $550 \pm 5^{\circ} \mathrm{C}$ in electric muffle furnace for $4 \mathrm{hr}$, thereafter dissolving the ashed sample using $10 \mathrm{ml}$ of $6 \mathrm{~N} \mathrm{HCl}$ then filtered in corning volumetric flask. The last traces of ash were dissolved and rinsed meticulously using de-ionized water before being filtered in the volumetric flask mentioned earlier. Finally, B concentration in thus prepared extract was assessed by using azomethine-H (Gupta, 1979).
Quality characteristics of cotton fibre: Important quality characteristics of cotton fibre viz. fibre strength and fineness (micronaire value), $2.5 \%$ staple length, and uniformity ratio were determined. Fibre strength ( $\mathrm{g} \mathrm{tax}^{-1}$ ) was determined after conditioning of fibre samples for $24 \mathrm{hr}$. A random cotton fibre sample was prepared and short fibres were separated. The data were used to preferred level by samples of selected values. Fibre fineness describing the micronaire value (Mic $9000 \mathrm{HVI}$ ) which expresses the weight of 1 inch of fibre in micrograms $\left(10^{-6} \mathrm{~g}\right)$ was determined using standard protocols to estimate the excellence value of cotton fibre. For this, a known weight of conditioned sample was compressed in a cylinder to a known volume and was subjected to air current at a known pressure.

The rate of air flow through porous plug of fibre was taken as a measure of fineness of cotton lint. A $2.5 \%$ staple or fibre length $(\mathrm{mm})$ were evaluated at Fibre Quality Laboratory of P.A.U., Ludhiana, (India) using high volume instrumentation (Mic. 9000 $\mathrm{HVI}$ ) after conditioning the fibre for $24 \mathrm{hr}$. A narrow rectangular beam of light was allowed to fall on specimen beard, and the attenuation of light through the specimen at different areas of the beard was measured to estimate staple length. The lint characteristics included seed index, ginning out turn (G.O.T), lint index. Seed index (g) was measured using weight of 100 healthy seeds. The percent G.O.T. was estimated using $20 \mathrm{~g}$ clean seed cotton sample for each plant. Sample was ginned with a single roller electric ginto obtain lint. Lint was weighted to calculate ginning outturn percentage. Lint index describing the weight of lint produced by 100 seeds (g) was also determined.

Statistical analyses: Statistical analysis of data on various B pools, seed cotton, lint yield and fibre quality attributes was performed by one way ANOVA in RBD. Mean separation for different treatments was performed using least significant difference (LSD) test using SPSS 16 (Chicago, U.S.A.). Differences in treatment mean at $p<0.05$ were considered statistically significant. Further, the correlation matrix was developed using SPSS 16 package, and relationships significant at $p<0.05$ and $p<0.01$ were marked as ${ }^{*}$ and ${ }^{* *}$, respectively.

\section{Results and Discussion}

The influence of boron application (soil incorporation) was estimated in different vegetative parts viz. roots, monopodial branches, sympodial branches, petioles, leaves, bolls, cotton seed and lint (Table 1). Data showed that boron concentration did not differ conspicuously among two sources. The augmentation in B concentration was significant with raised rates of $B$ application. Its concentration in cotton roots ranged between 8.5 and $19.6 \mathrm{mg} \mathrm{kg}^{-1}$, and manifested a significant increase with $B$ application. Thus, the mean boron content of cotton roots increased by 37.6, 74.1, $91.8,110.6$ and $130.6 \%$ with $B$ application at $B_{0.5}, B_{1.0}, B_{1.5}, B_{2.0}, B_{2.5}$ $\mathrm{mg} \mathrm{B} \mathrm{kg}{ }^{-1}$ soil, respectively over control. Mean $B$ content in cotton roots amplified by $\sim 75.3$ and $73.1 \%$, respectively with $B$ application through Borax and Granubor. Boron content in monopodial branches augmented significantly under $B_{1.0}$ treatment. Further assessment of data manifested that the mean $B$ 


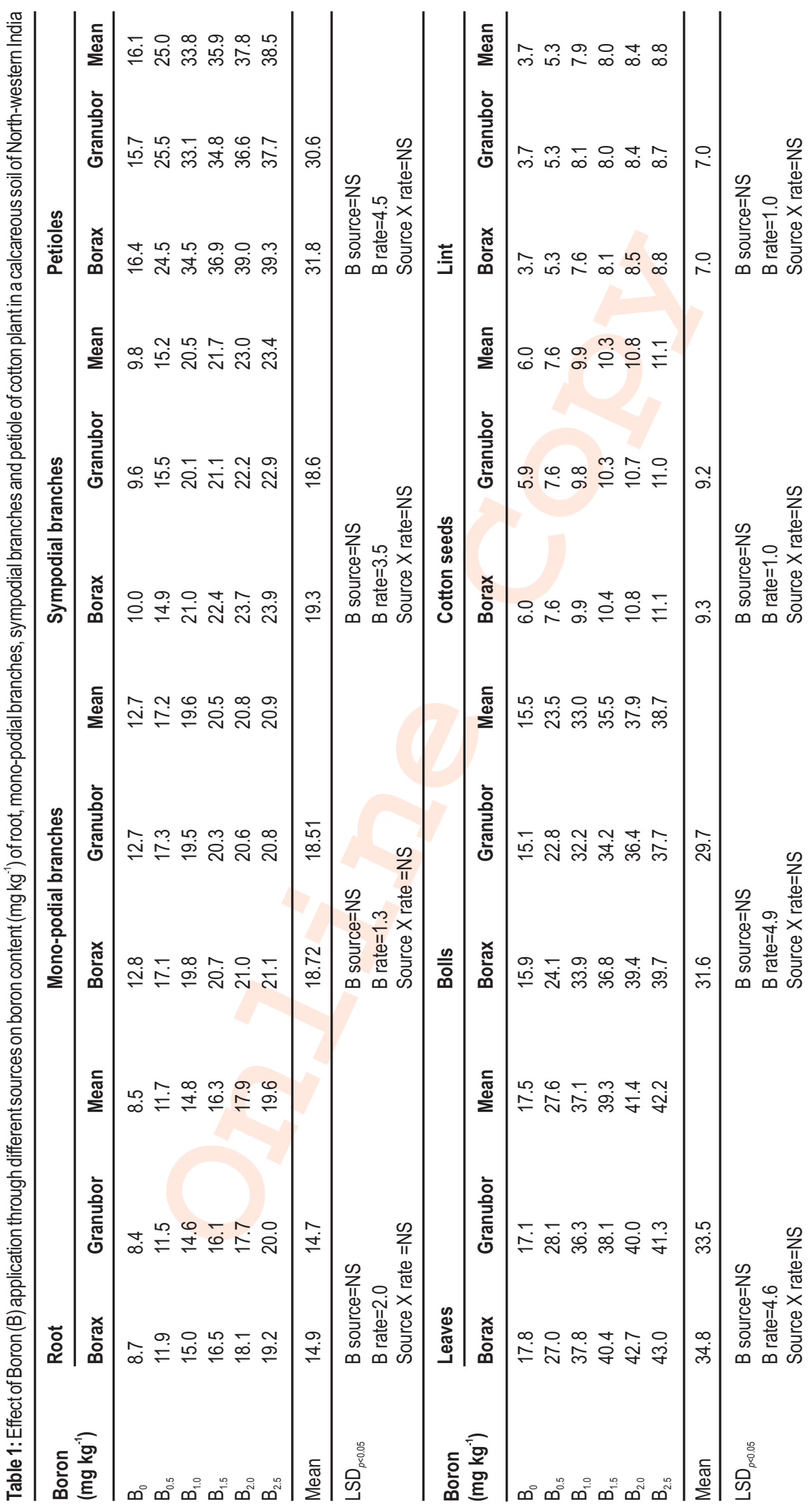

- Journal of Environmental Biology, November 2021 • 
concentration in monopodial branches built up significantly by $14.0 \%$ under $B_{1.0}$, compared with $B_{0.5}$. Consequently, the $B$ concentration in monopodial branches augmented by $35.2,54.6$, $61.2,63.8$ and $64.7 \%$ under $B_{0.5}, B_{1.0}, B_{1.5}, B_{2.0}$ and $B_{2.5}$ treatments, respectively over $B_{0}$. Likewise, $B$ concentration in sympodial branches of cotton surged through $B$ application by $~ 55.1,109.2,121.4,134.7$ and $138.8 \%$, respectively over $B_{0}$. Boron concentration in cotton petioles increased by $\sim 35.2 \%$ under $B_{10}$ treatment, compared with $B_{0.5}$. Boron concentration in cotton leaves ranged from 17.5 to 42.2 $\mathrm{mg} \mathrm{kg}^{-1}$, and amplified significantly by $\sim 112 \%$ with $\mathrm{B}$ application under $\mathrm{B}_{1.0}$ treatment, compared with $\mathrm{B}_{0}$ (Table 1$)$.

Further, the mean $\mathrm{B}$ concentration in leaf biomass increased by $57.7,112.0,124.6,136.6,141.1 \%$ with soil application at $0.5,1.0,1.5,2.0,2.5 \mathrm{mg} \mathrm{B} \mathrm{kg}^{-1}$ soil, respectively than control. Thereafter, B concentration in bolls, cotton seeds and lint augmented significantly under $\mathrm{B}_{2.5}$ treatment. Boron concentration in different plant parts of cotton followed the order: leaves $>$ petioles $\approx$ bolls $>$ sympodial branches $\approx$ monopodial branches $>$ roots $>$ cotton seed $>$ lint. Boron is conveyed from the roots to the shoot via xylem by mass flow under power of transpiration tug (Kochian, 1991) and amasses higher quantity of $B$ at the tips and margins of older leaves than in other parts of plant. These outcomes are in compliance to earlier research findings that showed that increased $B$ concentration was ascribed to enhance absorption of soil applied $B$, and its accumulation in different vegetative plant parts under influence of transpiration tug (Boparai and Manchanda, 2019; Atique-ur-Rehman et al., 2020). The non-uniform allocation of $B$ among different parts of cotton in our experimental outcomes has been ascribed to its immobile nature or very limited mobility in phloem of cotton (Gormus and Barutcular, 2016; Boparai and Manchanda, 2019).

Lint yield augmented remarkably with $B$ application $\left(B_{0.5}\right)$, compared with $B_{0}$ (Table 2). Boron application at higher rate $\left(B_{1.0}\right)$ resulted in further significant increase of $\sim 8.8 \%$, compared with $\mathrm{B}_{0.5}$. Mean lint yield exhibited a significant increase under $\mathrm{B}_{1.0}$ treatment, and further increase in $B$ application rates brought nonsignificant change in lint yield. In contrast to $B_{0}$, augmentation in cotton seed yield remained non- significant under $B_{0.5}$. Nonetheless, soil incorporation of $B$ at elevated rate $\left(B_{1.0}\right)$ brought about significant augmentation in mean cotton seed yield by $\sim 15.9 \%$, compared with $B_{0}$. With further surge in boron application rate, the augmentation in seed cotton yield stayed statistically similar with preceding application rates. Similar findings were also reported in earlier research (Atique-ur-Rehman et al., 2020; Kumar et al., 2021). Boron application through either source revealed trivial impact on the percentage of G.O.T., seed index along with lint index (Table 2). Boron paucity cause alteration in chemical composition and ultra-structure of cell wall, amassing of toxic phenols, inhibition of lignin synthesis and resulted in decreased production of indole acetic acid, which further induces Ca deficiency in plants (Rattan and Goswami 2009). Further, boron application augments plant growth by altering IAA content and intervening IAA metabolism (Li et al., 2016). Boron deficiency causes significant set-back on the activity/concentrations of cytokinins in plants that hamper cell division, possibly through an involvement in RNA metabolism. Considering the afore narrated literature, it can be infered that B plays multiple roles that contribute towards increased growth, yield and its attributing parameters of crops grown in soil deficient in boron.

Fibre quality was appraised through uniformity ratio, micronaire, strength and staple length of cotton's fibre with B application through different sources (Fig. 1). These quality traits did not differ appreciably with $B$ application from two sources. The mean uniformity ratio varied between 44.6 and $47.0 \%$, and exhibited a significant increase with $B$ application under $B_{2.0}$ by $\sim 4.8 \%$, compared with $B_{0}$. The mean fibre strength and fibre length significantly improved with $B$ application under $B_{1.5}$ treatment, compared with $B_{0}$. These quality characteristics did not differ appreciably with augmented boron application rates. Boron application resulted in a significant decrease in micronaire from $4.84 \mu$ inch $^{-1}$ under $B_{0}$ to $4.25 \mu$ inch $^{-1}$ under $B_{25}$. The decrease in micronaire was noteworthy with $B_{1.5}$ application, with the highest decrease under $B_{2.5}$. The mean staple length of cotton fibre increased by $1.9,5.2,9.2,10.6$ and $12.5 \%$ with $B$ application under $\mathrm{B}_{0.5}, \mathrm{~B}_{1.0}, \mathrm{~B}_{1.5}, \mathrm{~B}_{2.0}$ and $\mathrm{B}_{2.5}$ treatments, respectively over $\mathrm{B}_{0}$. These results are in compliance with a previous study showing a significant linear relationship between $B$ application and lint characteristics influencing its quality (Rahman et al., 2018; Atique-ur-Rehman et al., 2020).

The sequential speciation of total $B$ content amidst different fractions was appraised to quantify the effect of $B$ application. A finer perusal of data manifested that oxide-bound $B$ pool was the smallest fraction, comprising $\sim 0.34 \%$ of total $B$ pool (Table 3; Fig. 2). In contrast, the residual B pool comprised the largest fraction ( 95\%). The soluble B accounts for merely $\sim 0.6 \%$ of the total $B$ concentration. Boron application $\left(B_{0.5}-B_{2.5}\right)$ significantly increased (64.7-311.8\%) soluble fraction in soil, than $B_{0}$. The adsorbed $B$ pool augmented drastically by $52.5-327.9 \%$ in response to different levels of soil applied $B\left(B_{0.5}-B_{2.5}\right)$, as compared to $B_{0}$. Oxide bound $B$ fraction also augmented appreciably from 21.7 to $282.6 \%$ with raising levels of $B$ application, over $\mathrm{B}_{0}$. Furthermore, soil organic matter $\mathrm{B}$ pool varied between 0.67 and $2.73 \mathrm{mg} \mathrm{kg}$, and manifested considerable augmentation by $\sim 50.4-310.5 \%$ in response to raising levels of soil applied $B\left(B_{0.5}-B_{25}\right)$, as compared with $B_{0}$. Likewise residual $B$, the largest $B$ fraction exhibited a significant response to $B$ application, compared with $B_{0}$. Relative order of preponderance of various forms was in the following order: oxidebound < soluble < adsorbed < soil organic matter < residual B. Soil application distributes $B$ among constituents which stay in a dynamic equilibrium. There are several soil properties viz. $\mathrm{pH}$, oxidizable-SOC, several clay minerals, sesqui-oxides and carbonates that influence soil chemistry of $B$ added to soil environment and transform it into various $B$ pools of different solubility (Tsalidas et al., 1994). Among these, soluble B fraction has been considered easily available form for plant roots.

The results are in compliance to earlier outcomes showing that soluble boron pool as the smallest fraction of the total sum of all boron pools under varied agro-climatic 

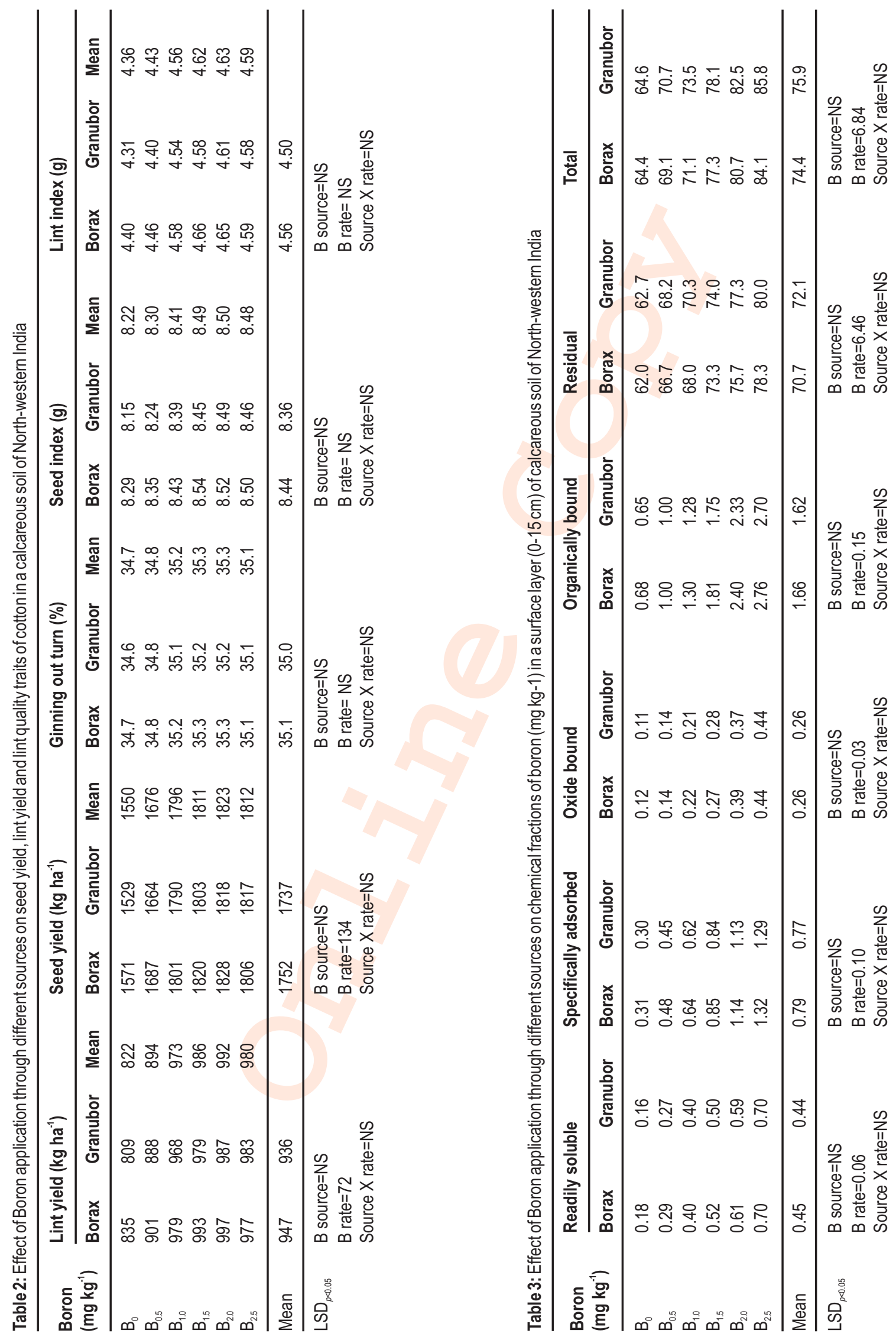

- Journal of Environmental Biology, November 2021 • 


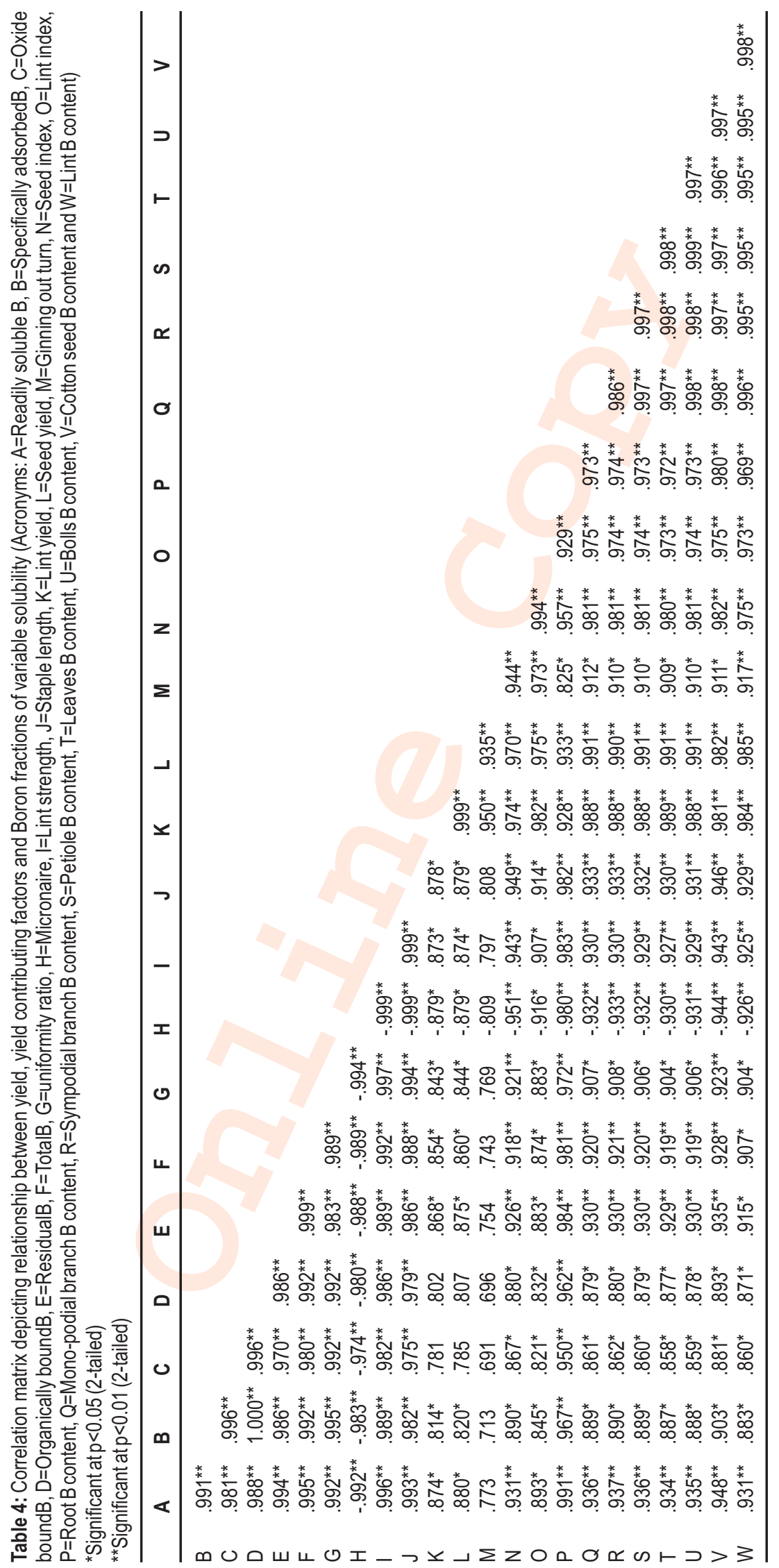



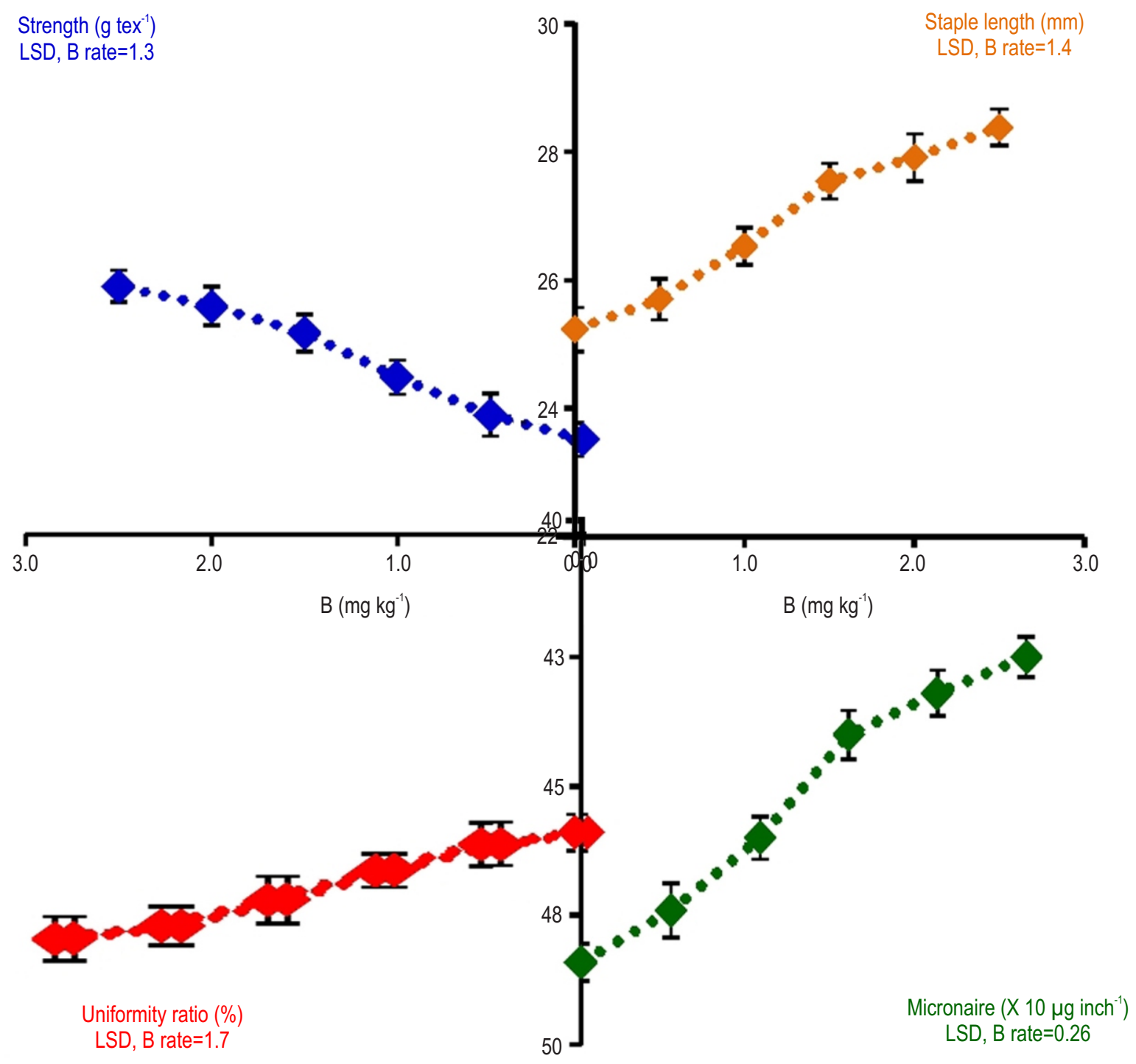

Fig 1: Effect of soil application of Boron on cotton fibre quality traits viz. lint strength, staple length, uniformity ratio and micronaire values of cotton grown in a calcareous soil of North-western India.

circumstances (Sidhu and Kumar, 2018; Boparai and Manchanda, 2019). The adsorbed pool represents boron fraction adsorbed on phyllosilicate clay surfaces (Goldberg et al., 1993), available to growing plant roots (Tsalidas et al., 1994). The mean concentration of adsorbed boron (0.31-1.31 $\left.\mathrm{mg} \mathrm{kg}^{-1}\right)$, comprising $0.48-1.57 \%$ of total pool was in range as reported earlier (Xu et al., 2001). The readily and/or specifically adsorbed boron pool augmented with raising soil application rates because of its adsorption on the surface of various clay minerals (Padbhushan et al., 2019). Oxide bound fraction typify strongly chemisorbed boron on sesqui-oxides and Mn-oxide, formed an integral constituent of lattice structure, and become the least available pool which gets adsorbed and translocate into stable pools. These results revealed that oxide-bound fraction was the smallest $B$ fraction $\left(0.11-0.44 \mathrm{mg} \mathrm{kg}^{-1}\right)$, comprising $\sim 0.34 \%$ of total pool. The most likely explanation for this smallest $B$ fraction has been low concentration of sesquioxides in the soils of prevailing semi-arid climate with ample amount of $\mathrm{CaCO}_{3}$. In alluvial soils, sesqui-oxide bound fraction has been the smallest boron fraction of total pool (Padbhushan et al., 2019). Further, the soil organic matter associated B fraction forms organo-mineral association by ligand exchange. Organic matter adsorbs B in unavailable form for crops. The experimental outcomes manifested that higher proportion of $B$ was bound/allied with soil organic matter as compared with sesqui-oxides (Padbhushan et al., 2019). Residual fraction, fixed within crystal structure of soil constituents' (primary as well as secondary soil minerals) has been the non bio-available $B$ 


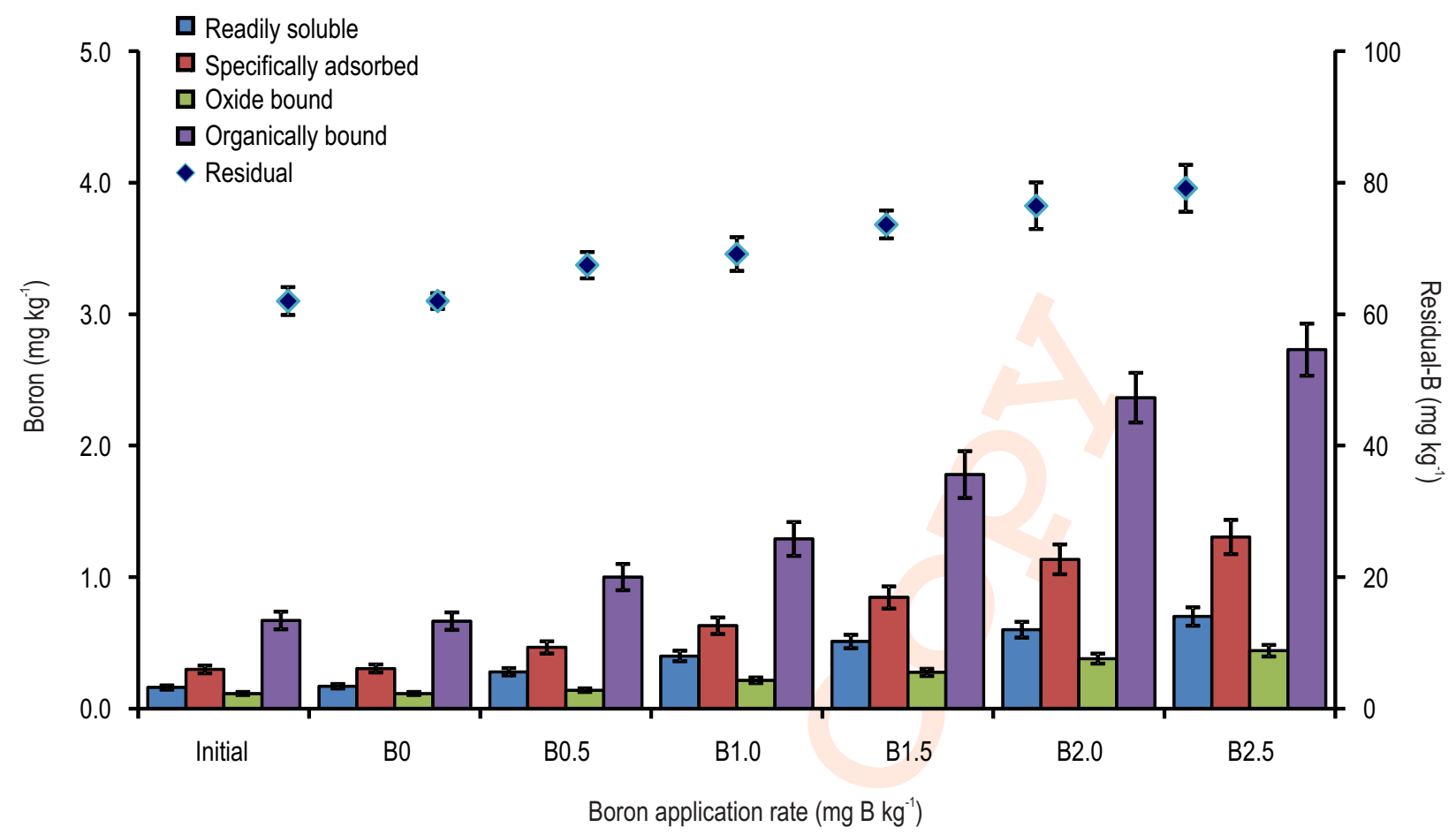

Fig. 2: Effect of soil application of Boron on distribution of Boron among fractions of different solubility in a calcareous soil of North-western India (data pooled for B sources). Line bars indicate standard error from mean.

fraction. The mean residual B concentration of $62-80 \mathrm{mg} \mathrm{kg}^{-1}$, comprised between $93.2-96.2 \%$ of total B. Further, the predominance of residual B fraction ( $>90 \%$ ) in soils of different agro-climatic regions also has a plenty of documentation (Kaundal et al., 2014; Padbhushan and Kumar, 2015; Boparai and Manchanda 2019). Increase in total B concentration with escalating B application level was ascribed to its adsorption on soil constituents.

Boron fractions including soluble, adsorbed, sesquioxide bound and soil organic matter bound fractions exhibited a linear positive relationship with cotton's fibre quality attributes and $B$ uptake in various vegetative parts (Table 4). These fractions exhibited a significant association with seed yield and lint yield of cotton. Additionally, there exists a linear relationship of various B fractions of variable solubility with total B pool. Micronaire value exhibited a noteworthy linear negative alliance with soluble $\left(\mathrm{r}=-0.992^{* *}, \quad p<0.01\right)$, adsorbed $\left(\mathrm{r}=-0.983^{* *}\right.$, $p<0.01)$, sesqui-oxide $\left(r=-0.974^{* *}, p<0.01\right)$, soil organic matter bound $\left(r=-0.986^{* *}, p<0.01\right)$ and residual $B\left(r=-0.988^{* *}, p<0.01\right)$. Lint strength, staple length and uniformity ratio exhibited a linear correlation with different B pools. The B concentration in different vegetative parts of cotton was linearly related to its fractions of variable solubility. Previous research also showed positive and significant correlation among various fractions and $B$ concentration in different vegetative parts and crop yield (Tisdale et al., 1994; Dey et al., 2015 ; Padbhushan et al., 2019).
The correlation matrix indicating significant relationship between $B$ pools of variable solubility showed interdependency of various fractions in soils with high concentration of $\mathrm{CaCO}_{3}$. The higher value of correlation coefficient for soluble sesqui-oxide bound and soil organic matter bound $B$ fraction implies that these fractions serve as buffer stock of $B$ supplying capacity of soils. These experimental outcomes highlight significance of $\mathrm{B}$ application in cotton cultivation in a B deficient calcareous soil for increased seed cotton productivity. Further, boron application brought about a considerable enlargement of total and labile B pool, which increased the yield attributes and quality characteristics due to enhanced B uptake by different vegetative parts.

\section{Acknowledgments}

First author is thankful to the Regional Research Station, P.A.U., Bathinda and Department of Soil Science, Punjab Agricultural University, Ludhiana for providing all the necessary facilities required for field experiment and laboratory work.

\section{Add-on Information}

Authors' contribution: S. Kumar: Carried out research and drafted the manuscript; D. Kumar: Major advisor of research work; K.S. Sekhon and O.P. Choudhary: Co-major advisor of research work and edited the manuscript; P. Singh and M. Phogat: Statistical analysis, data presentation and manuscript 
writing.

Research content: The research content is original and has not been published elsewhere.

\section{Ethical approval: Not applicable.}

Conflict of interest: The authors declare that there is no conflict of interest.

\section{Data from other sources: Not applicable.}

Consent to publish: All authors agree to publish the paper in Journal of Environmental Biology.

\section{References}

Arora, S. and D.S. Chahal: Available boron content in some benchmark soils of Punjab under different moisture regimes in relation to soil characteristics. Agropedology, 15, 90-94 (2005).

Atique-ur-Rehman, R. Qamar, A. Hussain, H. Sardar, N. Sarwar, H.M.R. Javeed, A. Maqbool and M. Hussain: Soil applied boron (B) improves growth, yield and fiber quality traits of cotton grown on calcareous saline soil. PLoS ONE, 15, e0231805 (2020).

Berger, K.C. and E. Truog: Boron tests and determination for soils and plants. Soil Sci., 57, 25-36 (1944).

Birnbaum, E.H., C.A. Beasley and W. M. Dugger: Boron deficiency in unfertilized cotton (Gossypium hirsutum L.) ovules grown in vitro. Plant Physiol., 54, 931-935 (1974).

Boparai, A.K. and J.S. Manchanda: 2019. Response of cotton and wheat cultivars to soil-applied boron in a boron-deficient, non calcareous typic ustochrept. Commun. Soil Sci. Plant Anal., 50, 108-118 (2019).

Dey, A., B.S. Dwivedi, S.P. Datta, M.C. Meena and B.K. Agarwal: Soil boron status: Impact of lime and fertilizers in an Indian long-term field experiment on a Typic Paleustalf. Acta Agric. Scand. Sect. B Soil Plant Sci., 65, 54-62 (2015)

Goldberg, S., H.S. Forster and E.L. Heick: Boron adsorption mechanisms on oxides, clay minerals and soils inferred from ionic strength effects. Soil Sci. Soc. Am. J., 57, 704-708 (1993).

Gormus, O. and C. Barutcular: Boron nutrition studies with cotton and sunflower in southern turkey. Commun. Soil Sci. Plant Anal.,47, 915-929 (2016).

Gupta, U.C.: Boron nutrition of crops. Adv. Agron., 31, 273-307 (1979).

Hearn, A.B.: Cotton nutrition. Field Crop Abstr., 34, 11-34 (1981).

Hou, J., L.J. Evans and G.A. Spiers: Chemical fractionation of soil boron. I. Method development. Can. J. Soil Sci., 76, 485-491 (1996).

Jin, J., D.C. Martens and L.W. Zelazny: Distribution and plant availability of soil; boron fractions. Soil Sci. Soc. Am. J., 51, 1228-1231 (1987).

Kochian, L.V.: Mechanisms of micronutrient uptake and translocation in plants. In: Micronutrient in Agriculture. (Eds.: J.J. Mortvedt, F.R. Cox, L.M. Shuman and R.M. Welch). Soil Science Society of America. Madison, pp. 229-296 (1991).

Kaundal, A., S.K. Sharma, P. Kumar, N. Sankhyan and J. Dutta: Distribution of boron forms in relation to soil characteristics, chemical fertilizers and amendments in an acid alfisol of northwestern Himalayas. Commun. Soil Sci. Plant Anal., 45, 1772-1783 (2014).
Kumar, S., D. Kumar, K.S. Sekhon, P. Singh, M. Phogat, S. Kakralia and O.P. Choudhary: Effect of soil applied boron on depth-wise distribution of root biomass of cotton grown in a calcareous soil of North-western India. J. Soil Salin. Water Qual.,13, 79-85 (2021).

Li, Q., Y. Liu, Z. Pan, S. Xie and S. Peng: Boron deficiency alters root growth and development and interacts with auxin metabolism by influencing the expression of auxin synthesis and transport genes. Biotechnol. Biotech. Equip., 30, 661-668 (2016).

Padbhushan, R. and D. Kumar: Distribution of boron in different fractions in some alkaline calcareous soils. Commun. Soil Sci. Plant Anal., 46, 939-953 (2015).

Padbhushan, R., J. Mandal, S. Kumar and A. Kumar: Chemical fractions and response of cauliflower (Brassica oleraceavar. Botrytis) to soil applied boron. J. Plant Nutr., 42, 491-500 (2019).

Rahman, M.T., M.M. Haque, M.G.G. Mortuza, M.S. Hossain and R. Chakraborty: Influence of foliar boron application on ginning traits, fiber and seed quality of cotton. J. Exp. Agric. Int., 23, 1-6 (2018).

Rashidi, M., M. Seilsepour and M. Gholami: Response of yield, yield components and fiber properties of cotton to different application rates of nitrogen and boron. Am. Eurasian J. Agric. Environ. Sci., 10,525-531 (2011)

Rattan, R.K. and N.N. Goswami: Mineral nutrition of plants. In: Fundamentals of Soil Science (Eds.: N.N Goswami, R.K. Rattan, G. Dev, G. Narayanasamy, D.K. Das, S.K. Sanyal, D.K. Pal and D.L.N. Rao). Indian Society of Soil Science, New Delhi, India, pp. 349-385 (2009).

Sarkar, S., H. Banerjee, I. Chakraborty, S. Sau, K. Ray, D. Ghosh and P. Deb: Assessment of growth, yield, tuber quality and profitability of potato upon boron fertilization. J. Environ. Biol., 39, 365-372 (2018).

Sharma, J., V.K. Dua, D. Kumar and V. Sharma: Evaluation of colemanite as a slow release source of boron fertilizer for potato. J. Environ. Biol., 40, 240-244 (2019).

Shorrocks, V.M.: Boron - A global appraisal of the occurrence, diagnosis and correction of boron deficiency. In: International Symposium on the Role of Sulphur, Magnesium, and Micronutrients in Balanced Plant Nutrition. Portch, 39-53. Washington, D.C.: Sulphur Institute (1992).

Sidhu, G.S. and D. Kumar: Influence of soil applied boron on yield of berseem (Trifolium alexandrium L.) and soil boron fractions in calcareous soils. J. Plant Nutr., 41, 980-995 (2018).

Sims, J.R. and G.V. Johnson: Micronutrient soil tests. In: Micronutrients in Agriculture (Eds.: J.J. Mortvedt, F.R. Cox, L.M. Shuman and R.M. Welch). American Society of Agronomy and Soil Science Society of America. Madison, Wisconsin, USA, pp. 427-476 (1991).

Tewolde, H. and C.J. Fernandez: Fiber quality response of pima cotton to nitrogen and phosphorus deficiency. J. Plant Nutr., 26, 223-235 (2003).

Tsalidas, C.D., N. Yassoglou, C.S. Kosmas and C.H. Kallianou: The availability of soil boron fractions to olive trees and barley and their relationships to soil properties. Plant Soil, 162, 211-217 (1994).

Xu, J.M., K. Wang, R.W. Bell, Y.A. Yang and L.B. Huang: Soil boron fractions and their relationship to soil properties. Soil Sci. Soc. Am. J., 65, 133-138 (2001).

Yeates, S.J., G.A. Constable and T. McCumstie: Irrigated cotton in the tropical dry season III: Impact of temperature, cultivar and sowing date on fiber quality. Field Crops Res., 116, 300-307 (2010). 